Bidang ilmu: Gizi

\title{
HUBUNGAN ASUPAN ZAT GIZI MAKRO DAN IMT DENGAN SINDROM METABOLIK PADA PEGAWAI PERUSAHAAN TAMBANG
}

\author{
Niken Meldy Puryanti1), Ibnu Malkan Bakhrul Ilmi2), Taufik Maryusman³) \\ Fakultas Ilmu Kesehatan \\ Universitas Pembangunan Nasional Veteran Jakarta \\ nikenmeldypuryanti@upnvj.ac.id ${ }^{1)}$, ibnuilmi@upnvj.ac.id²),pembelajartaufik@gmail.com³)
}

\begin{abstract}
ABSTRAK
Latar Belakang: Sebagian besar tugas pegawai perusahaan yaitu bagian administrasi. Lingkungan pekerjaan dapat memengaruhi status gizi dan asupan pegawai. Kondisi Kesehatan yang buruk dapat memengaruhi produktivitas pegawai. Salah satu masalah kesehatan yaitu sindrom metabolik pada pegawai eksekutif Jakarta cukup besar hingga mencapai 21,58\%. Asupan zat gizi berlebih dan obesitas menjadi salah satu faktor memicu akumulasi penyakit menjadi sindrom metabolik. Tujuan: menganalisis hubungan asupan zat gizi makro dan IMT dengan sindrom metabolik pada pegawai Perusahaan Tambang. Metode: cross-sectional dengan purposive sampling melibatkan 62 pegawai. Data penelitian diperoleh dari wawancara food recall 24 jam via chat dan medical check-up bulan Maret 2020. Hasil: terdapat 4 orang $(6,5 \%)$ termasuk kriteria sindrom metabolik. Tidak ada hubungan antara asupan karbohidrat $(p=0,404)$, protein $(p=0,404)$, lemak $(p=285)$, IMT $(p=0,426)$ dengan sindrom metabolik. Diskusi: tidak ada hubungan antara asupan zat gizi makro (karbohidrat, protein dan lemak) dan IMT dengan sindrom metabolik.
\end{abstract}

Kata kunci : Zat Gizi Makro, IMT, Sindrom Metabolik, Pegawai

\begin{abstract}
Background: Most of the company's employees are administrative tasks. The work environment can affect the nutritional status and employee intake. Poor health conditions can affect employee productivity. One of the health problems is the metabolic syndrome in Jakarta executive employees is quite large to reach $21.58 \%$. High nutrient intake and obesity are among the factors triggering the accumulation of the disease into metabolic syndrome. This study aims to analyse relationship macronutrient and nutritional status (BMI) with metabolic syndrome in employees of Mining Company. Method: Cross-sectional studi with a purposive sampling involving 62 employees. Data were collected from food recall 24 hours interview via chat and medical check-up. Result: The result is the incidence of metabolic syndrome criteria were 4 employees. There were not relationship between carbohydrate $(p=0,404)$, protein $(p=0,404)$, fat $(p=285)$, and nutritional status $(B M I)(p=0,426)$ with metabolic syndrome. Discussion: There were not relationship between macronutrient (carbohydrate, fat, and protein) and nutrition status (BMI) with metabolic syndrome.
\end{abstract}

Keywords: Macronutrient, BMI, Metabolic Syndrome, Employee

Alamat korespondensi: Komplek TNI AL BLok F2 no 2, Kel. Ciangsana, Kec. Gunung Putri, Kab. Bogor Email: ibnuilmi@upnvj.ac.id Nomor Hp: 085649190409 


\section{PENDAHULUAN}

Pegawai yaitu seseorang yang digerakkan manajer secara langsung untuk menghasilkan karyakarya yang diharapkan perusahaan untuk mencapai tujuan perusahaan (Mukhlis, 2012, hlm.5). Lingkungan pekerjaan memengaruhi status gizi dan juga asupan makan (Davy et al., 2014). Pegawai yang memiliki status kesehatan kurang baik berdampak pada produktivitas menurun, biaya kesehatan, serta waktu kerja pegawai (Mitchell \& Bates, 2011, p. 93). Selain itu, tersebut memengaruhi kejadian penyakit tidak menular (PTM) sebesar 70\% penyebab kematian pegawai kantor (Afifah dkk., 2018). Faktor pemicu adanya penyakit degeneratif yaitu sindrom metabolik.

Sindrom metabolik menjadi salah satu masalah kesehatan terutama dibidang klinis meskipun bukan suatu penyakit. Prevalensi sindrom metabolik di dunia yaitu sekitar 20-25\%, sedangkan di Indonesia sekitar 23,34\% termasuk laki-laki (26,2\%) dan perempuan (21,4\%) (Driyah dkk., 2019, p. 216). Penelitian Soegondo dkk (2006) dalam Rachmah \& Utari (2013) menunjukkan bahwa di wilayah DKI Jakarta tahun 2006 angka prevalensi sindrom metabolik telah mencapai 28,6\%. Berdasarkan hasil penelitian Zahtamal dkk. (2014, hlm. 113) prevalensi sindrom metabolik pada pegawai perusahaan yaitu sebesar $21,58 \%$ dari total responden.

Sindrom metabolik memiliki kumpulan gejala yang dapat menimbulkan penyakit degeneratif (Rini, 2015, hlm. 88). Gejala sindrom metabolik meliputi peningkatan ukuran lingkar pinggang, peningkatan kadar triliserida darah. hipertensi, diabetes, dan kolesterol-HDL (High Density Lipoprotein) menurun (Kamso dkk., 2011, hlm.85). World Health Organization (WHO) dalam Rismayanthi dkk. (2019, hlm.34) menjelaskan bahwa seseorang dapat dinyatakan sindrom metabolik apabila mempunyai 3 dari 5 gejala.

Penelitian Kamso dkk. (2011, hlm.88), pada pegawai eksekutif di Jakarta dan sekitarnya yang menjadi determinan sindrom metabolik yaitu IMT $>25 \mathrm{~kg} / \mathrm{m}^{2}$. Frekuensi kriteria sindrom metabolik dalam penelitian Zahtamal dkk. (2014, hlm.113) yang tertinggi yaitu obesitas sentral. Selain itu, distribusi frekuensi sindrom metabolik terbanyak pada kelompok pegawai yang mengonsumsi karbohidrat, lemak, dan protein tidak sesuai dengan diet dengan frekuensi berturut-turut yaitu $73,50 \%, 58,80 \%$, dan $82,40 \%$.

Asupan zat gizi makro dapat memengaruhi indeks massa tubuh (IMT) dikarenakan diet tinggi lemak meningkatkan obesitas. Selain itu, IMT terdapat hubungan dengan karbohidrat (Zahtamal dkk., 2014, hlm.118). Kondisi tingginya akumulasi pada jaringan lemak terutama pada lemak viseral ditandai dengan pembesaran sel-sel lemak sehingga memproduksi produk metabolik (Jafar, 2012, hlm.72). Peningkatan metabolisme lemak mengakibatkan peningkatan produksi ROS di sirkulasi maupun adiposa sehingga terjadi ketidakseimbangan reduksi dan oksidasi (redoks) serta enzim antioksidan di sirkulasi terganggu (Jafar, 2012, hlm.72).

Salah satu kantor yang memiliki aktivitas administrasi yaitu perusahaan batu bara yang bernama Perusahaan Tambang terletak di Jakarta Utara. Setiap lantai kantor difasilitasi air minum, dan kopi seduh. Sebelum pegawai datang, setiap botol minum telah diisikan oleh office boy dan diletakkan sesuai meja pegawai. Selain itu, pegawai memiliki cemilan pribadi di meja kerjanya, seperti kacang goreng, kerupuk, usus krispi, coklat bubuk, dan wafer. Pegawai disediakan makan siang dari perusahaan dengan menu yang berbeda dan sesuai standar. Setiap siang pegawai mendapatkan makan secara prasmanan, dan diberikan food model porsi makanan. Penerapan tersebut tidak diikuti oleh semua pegawai. Sebagian pegawai memilih beli makanan dari food court mall samping kantor seperti bakso, dan pecel ayam. Berdasarkan permasalahan tersebut, peneliti ingin mengetahui hubungan asupan zat gizi makro dan IMTdengan sindrom metabolik pada pegawai Perusahaan Tambang

\section{METODE PENELITIAN}

Teknik pengambilan sampel secara purposive sampling. Penelitian ini dengan teknik observasional dan desain cross-sectional. Tempat penelitian yaitu Perusahaan Tambang yang terletak di Jakarta Utara. Berdasarkan perhitungan besaran sampel menggunakan rumus Lemeshow (1990) dalam Notoatmodjo (2012) dibutuhkan sebanyak 42 orang. Jumlah sampel yang didapat yaitu 
sebanyak 62 orang. Data dikumpulkan melaui google form, link tersebut dibagikan dalam grup WhatsApp pegawai perusahaan.

Alat penelitian yang diperlukan yaitu google form, sedangkan bahan penelitian yaitu karakteristik responden, berat badan, tinggi badan, asupan zat gizi responden, kadar glukosa darah, kadar HDL kolesterol, kadar trigliserida, tekanan darah, dan obesitas sentral. Penelitian dilakukan di Perusahaan Tambang, Jakarta Utara. Data penelitian dibagi menjadi dua yaitu data primer dan data sekunder. Data primer terdiri dari tinggi badan, berat badan, dan food recall 24 jam diperoleh dari hasil kuesioner dan wawancara. Data sekunder diperoleh dari hasil medical check-up Perusahaan Tambang. Variabel dalam penelitian ini yaitu asupan zat gizi makro, IMT dan sindrom metabolik.

Asupan karbohidrat didapat dengan indikator asupan kurang $<80 \%$, asupan cukup 80-110\%, dan asupan lebih $>110 \%$ dari AKG. Asupan lemak menggunakan indikator median $(59,925)$, dengan asupan cukup $\leq$ median, dan lebih < median. Sedangkan asupan protein dengan asupan cukup $\leq 110 \%$, dan lebih $>110 \%$ dari AKG. IMT didapat dengan indikator dari mean $(25,519)$, sehingga tidak obesitas $\leq$ mean, dan obesitas $>$ mean. Sindrom metabolik menggunakan indikator NCEP ATP-III kadar trigliserida $\geq 150 \mathrm{mg} / \mathrm{dl}$, kadar HDL kolesterol laki-laki $<40 \mathrm{mg} / \mathrm{dl}$ wanita $<50 \mathrm{mg} / \mathrm{dl}$, kadar gula darah puasa $\geq 110 \mathrm{mg} / \mathrm{dl}$, tekanan darah sistolik $>130 \mathrm{mmHg}$ diastolik $>80 \mathrm{mmHg}$, obesitas sentral dengan lingkar pinggang wanita $>88 \mathrm{~cm}$ sedangkan laki-laki $102 \mathrm{~cm}$ (Rini, 2015). Rasio lingkar pinggang tersebut tidak valid jika digunakan untuk kawasan Asia sehingga disesuaikan menjadi lingkar pinggang wanita $>80 \mathrm{~cm}$, dan laki-laki $>90 \mathrm{~cm}$ (Widyastuti et al., 2013).

Analisis meliputi analisis univariat dan analisis bivariat. Analisis bivariat dengan aplikasi SPSS menggunakan uji chi-square untuk melihat hubungan asupan zat gizi makro dan IMT dengan sindrom metabolik. Berdasarkan hasil analisis, hipotesis penelitian diterima jika $p$-value $<a-s i g(0,05)$ sedangkan hipotesis ditolak jika $p$-value > a-sig $(0,05)$.

\section{HASIL DAN PEMBAHASAN}

Karakteristik responden berdasarkan usia jenis kelamin, dan divisi pekerjaan dapat dilihat pada tabel dibawah ini.

Tabel 1. Karakteristik Responden Penelitian

\begin{tabular}{lcc}
\hline \multicolumn{1}{c}{ Karakteristik } & $\mathbf{n}=\mathbf{6 2}$ & $\mathbf{\%}$ \\
\hline Usia & & \\
$19-29$ & 11 & 17,7 \\
$30-49$ & 48 & 77,4 \\
$50-64$ & 3 & 4,8 \\
\hline Jenis Kelamin & & \\
Laki-laki & 47 & 75,8 \\
Perempuan & 15 & 24,2 \\
\hline Divisi & & \\
HR & 14 & 22,6 \\
IT & 2 & 3,2 \\
HR & 14 & 22,6 \\
GS & 11 & 17,7 \\
FATB & 1 & 1,6 \\
PSCM & 4 & 6,5 \\
IARA & 1 & 1,6 \\
LEGAL & 1 & 1,6 \\
BUSDEV & 2 & 3,2 \\
SSO & 1 & 1,6 \\
ESG & 1 & 1,6 \\
LC & 8 & 12,9 \\
QC & 1 & 1,6 \\
BE & 1 & 1,6 \\
\hline
\end{tabular}


Karakteristik berdasarkan usia sebagian besar pegawai berusia 30-49 tahun dengan jumlah 48 responden (77,4\%). Jumlah pegawai berdasarkan jenis kelamin sebagian besar yaitu laki-laki sebanyak 47 responden. Responden terbanyak yaitu dari divisi HR dan COE sebanyak 14 responden $(22,6 \%)$.

\section{Kejadian Sindrom Metabolik}

Tabel 2. Gambaran Kejadian Sindrom Metabolik

\begin{tabular}{lcc}
\multicolumn{1}{c}{ Indikator } & $\mathbf{n}$ & $\mathbf{\%}$ \\
\hline Tanpa indikator & 21 & 33,9 \\
Satu indikator & 25 & 40,3 \\
Dua indikator & 12 & 19,4 \\
Tiga indikator & 3 & 4,8 \\
Empat indikator & 0 & 0 \\
Lima indikator & 1 & 1,6 \\
\hline Total & $\mathbf{6 2}$ & $\mathbf{1 0 0}$ \\
\hline
\end{tabular}

Berdasarkan Tabel 2 hasil data MCU menggambarkan jumlah responden yang memiliki indikator kurang dari tiga yaitu 58 pegawai $(93,5 \%)$, sedangkan jumlah pegawai yang lebih besar sama dengan tiga indikator yaitu empat pegawai (6,5\%). Berdasarkan hasil tersebut maka insiden sindrom metabolik pada perusahaan yaitu sebanyak empat kasus dari 62 responden $(6,5 \%)$. Hal itu didukung oleh penelitian terdahulu pada tahun 2019, menunjukkan persentase yang tidak berbeda signifikan jumlah responden termasuk sindrom metabolik yaitu sebanyak enam responden dari 162 responden atau sebesar 3,7\%. Persentase insiden sindrom metabolik pada perusahaan dibawah $10 \%$ jumlah responden sejalan dengan hasil penelitian Driyah et al., (2019) dalam studi kohort menunjukkan sebanyak 24 responden mengalami sindrom metabolik dari total 4.125 responden atau hanya sebesar $5,69 \%$.

Tabel 3. Distribusi Asupan Zat Gizi Makro dan IMT dengan Sindrom Metabolik

\begin{tabular}{|c|c|c|c|c|c|c|c|}
\hline \multirow{3}{*}{ Variabel } & \multicolumn{4}{|c|}{ Sindrom Metabolik } & \multirow{2}{*}{\multicolumn{2}{|c|}{ Total }} & \multirow{3}{*}{ pvalue } \\
\hline & \multicolumn{2}{|c|}{ Tidak } & \multicolumn{2}{|c|}{ Ya } & & & \\
\hline & $\mathbf{n}$ & $\%$ & $\mathbf{n}$ & $\%$ & $\mathbf{n}$ & $\%$ & \\
\hline \multicolumn{8}{|l|}{ Karbohidrat } \\
\hline Kurang & 53 & 85.5 & 4 & 6,5 & 57 & 91,9 & 0,404 \\
\hline Cukup & 5 & 8,1 & 0 & 0 & 5 & 8,1 & \\
\hline Total & 58 & 93,5 & 4 & 6,5 & 62 & 100 & \\
\hline \multicolumn{8}{|l|}{ Lemak } \\
\hline Cukup & 30 & 48,4 & 1 & 1,6 & 31 & 50 & 0,291 \\
\hline Lebih & 28 & 45,2 & 3 & 4,8 & 31 & 50 & \\
\hline Total & 58 & 93,6 & 4 & 6,4 & 62 & 100 & \\
\hline \multicolumn{8}{|l|}{ Protein } \\
\hline Cukup & 50 & 80,6 & 4 & 6,5 & 54 & 87,1 & 0,285 \\
\hline Lebih & 8 & 12,9 & 0 & 0 & 8 & 12,9 & \\
\hline Total & 58 & 93,5 & 4 & 6,5 & 62 & 100 & \\
\hline \multicolumn{8}{|l|}{ IMT } \\
\hline Tidak Obesitas & 31 & 50 & 1 & 1,6 & 32 & 51,6 & 0,262 \\
\hline Obesitas & 27 & 46,6 & 3 & 1,8 & 30 & 48,4 & \\
\hline Total & 58 & 96,6 & 4 & 6,5 & 62 & 100 & \\
\hline
\end{tabular}




\section{Karbohidrat}

Pada tabel 3, semua responden yang termasuk sindrom metabolik memiliki asupan karbohidrat kurang yaitu sebanyak empat responden (6,5\%). Asupan karbohidrat responden sebagian besar masih kurang dari kebutuhan sehari yaitu sebanyak 57 responden (91,9\%). Hasil tersebut, didukung oleh penelitian terdahulu pada tahun 2019 rata-rata asupan karbohidrat yaitu 217,56 gram dengan rentang asupan sebesar 85,1 gram sampai 356,5 gram dengan jumlah 154 responden (95\%) memiliki asupan karbohidrat kurang, dan delapan responden (5\%) asupan karbohidrat cukup.

Hasil analisis didapat $p$ value 0,404 sehingga tidak ada hubungan antara asupan karbohidrat dengan sindrom metabolik. Berbeda dengan penelitian Driyah dkk. (2019, hlm.219), pada studi kohort selama enam bulan di Bogor, hasil penelitian tersebut menyatakan bahwa asupan karbohidrat menjadi salah satu prediktor sindrom metabolik dengan $p$-value sebesar 0,01 .

Metabolisme karbohidrat dapat penghambatan mitokondrial $\beta$ oxidation, mendukung lipogenesis yang dapat menyebabkan penumpukan lemak dalam tubuh, menghambat pembentukan trigliserida, dan meningkatkan ROS (Lim et al., 2010). Selain itu, juga dapat menghambat mitokondrial $\beta$ oxidation, dimana peran mitokondrial $\beta$ oxidation membentuk energi hasil konversi dari lemak dalam keadaan puasa dan stress metabolik (Lim et al., 2010; Chegarya et al., 2009). Berdasarkan dampak asupan karbohidrat berlebih tersebut maka hal ini sangat mengkhawatirkan mengingat kejadian sindrom metabolik dalam hasil penelitian ini dapat terjadi pada asupan kurang. Hasil analisis penelitian ini sejalan dengan penelitian Putri \& Dieny (2016), menunjukkan $p$ value sebesar 0,185<0,05 yang berarti bahwa tidak ada hubungan yang signifikan antara asupan karbohidrat dengan sindrom metabolik.

\section{Lemak}

Pada tabel. 3, responden yang termasuk sindrom metabolik memiliki asupan lemak kurang yaitu sebanyak tiga responden (6,5\%). Asupan lemak responden sebagian besar termasuk kategori lebih dari kebutuhan sehari yaitu sebanyak 31 responden (50\%). Hasil analisis didapat $p$ value 0,291 sehingga tidak ada hubungan antara asupan lemak dengan sindrom metabolik.. Pada klub senam di Universitas Islam Negeri Syarif Hidayatullah Tahun 2013 dalam penelitian Fahad (2013, hlm.84) tersebut terdapat hubungan yang signifikan antara asupan lemak dengan kejadian sindrom metabolik. Selain itu, pada penelitian di kelompok remaja, terdapat hubungan kausal antara asupan lemak dengan sindrom metabolik (Sargowo \& Andarini, 2011, hlm.15).

Konsumsi makanan tinggi lemak jenuh dan kolesterol dapat menurunkan katabolisme sehingga kolesterol dalam darah akan meningkat terutama jenis LDL (Yuliantini dkk., 2015, hlm.140). Apabila LDL diatas normal dalam kurun waktu tertentu akan menyebabkan elastisitas pembuluh darah menurun dan meningkatkan risiko atheroskelrosis (Rini dkk., 2014, hlm.1). Hal itu disebabkan LDL dapat mengantarkan kolesterol menuju pembuluh darah dan menjadi plak sedangkan HDL membawa kolesterol kembali ke hati.

Sebagian responden sindrom metabolik memiliki asupan lemak lebih. Sejalan dengan hasil penelitian Ranti dkk (2013, hlm.133), dengan $p$ value 0,082 yang berarti pada pegawai dan staff Politeknik Kesehatan Manado tidak terdapat hubungan antara asupan lemak total dengan sindrom metabolik. Penelitian studi kohort prospektif selama enam tahun di kota Bogor mendapatkan hasil analisis hubungan asupan lemak dengan sindrom metabolik dengan $p$ value 0,261 yang berarti bahwa tidak ada hubungan yang signifikan antara asupan lemak dengan sindrom metabolik (Driyah dkk., 2019, hlm.217).

\section{Protein}

Pada tabel. 3, semua responden sindrom metabolik memiliki asupan protein termasuk kategori cukup yaitu sebanyak empat responden (6,5\%). Asupan protein responden sebagian besar termasuk kategori cukup dari kebutuhan sehari yaitu sebanyak 54 responden $(87,1 \%)$. Hasil analisis didapat $p$ value 0,285 sehingga tidak ada hubungan antara asupan protein dengan sindrom metabolik. Berbeda 
dengan penelitian Zahtamal dkk. (2014, hlm.117), distribusi frekuensi kasus sindrom metabolik sebesar 58,8\% memiliki asupan protein tidak sesuai dengan diet.

Protein dapat memberikan efek kenyang dan dipecah menjadi energi jika asupan karbohidrat dan lemah tidak mencukupi. Asupan protein berlebih akan mengalami deaminasi, dengan nitrogen dikeluarkan dan sisa ikatan karbon diubah menjadi lemak yang disimpan dalam tubuh. Sehingga kegemukan dapat disebabkan asupan protein berlebih (Almatsier, 2009, hlm.94).

Namun, hasil analisis penelitian ini semua responden sindrom metabolik memiliki asupan protein cukup sehingga hal ini sangat mengkhawatirkan jika sindrom metabolik dapat terjadi pada asupan cukup. Sejalan dengan penelitian Putri \& Dieny (2016, hlm.217), didapat $p$ value sebesar 1,00 yang berarti bahwa tidak ada hubungan antara zat gizi makro termasuk protein dengan sindrom metabolik. Selain itu, penelitian Fahad (2013, hlm.84), menunjukan hasil analisis dengan $p$ value sebesar 0,71 yang berarti tidak ada hubungan antara asupan protein dengan sindrom metabolik pada anggota klub senam.

Secara garis besar hasil food recall 24 jam asupan zat gizi makro responden termasuk kurang hingga cukup. Pada proses pengisian google form dan wawancara dilakukan pada saat bulan Ramadhan sehingga sebagian besar responden berpuasa sehingga asupan mengalami penurunan dan yterjadi perubahan pola makan (Perwiranti dkk., 2017, hlm.28; Al-Hourani, 2007). Hal tersebut memengaruhi hasil food recall 24 hours sehingga asupan responden menurun.

Berdasarkan analisis penyediaan makanan di perusahaan terkait dengan menggunakan standar kebutuhan sebesar $1.200 \mathrm{kkal}$ per porsi untuk sekali makan. Frekuensi pemberian makan yaitu tiga kali sehari untuk shift pagi dan siang, sedangkan shift malam diberikan sebanyak empat kali makan dalam sehari. Standar menu tersebut disediakan untuk pegawai dengan aktivitas ringan, sedang dan berat. Hal itu dapat menyebabkan makanan tidak habis, karena kebutuhan pekerja ringan hingga sedang berdasarkan Angka Kecukupan Gizi (AKG) 2004 sekitar 2200 kkal hingga 2300 kkal kebutuhan dalam sehari. Penelitian terdahulu tahun 2019 menjelaskan, alasan utama pegawai tidak menghabiskan nasi karena tektur keempukan, rasa, porsi, dan aroma sehingga dapat memengaruhi selera makan. Namun, pembagian porsi zat gizi perusahaan telah sesuai dengan ketetapan yang tercantum dalam Kementerian Kesehatan RI (Kemenkes RI) tahun 2017 bahwa kebutuhan asupan karbohidrat sekitar 50\% hingga 60\%, asupan lemak sekitar 20\% hingga 30\%, dan asupan protein sekitar 10\% hingga 20\% dari kebutuhan energi total (Damayanti dkk. 2017).

\section{IMT}

Gambaran IMT dalam tabel.3, sebagian besar responden sindrom metabolik termasuk kategori obesitas yaitu sebanyak tiga responden $(4,8 \%)$. Responden termasuk tidak obesitas sebanyak 32 responden $(51,6 \%)$. Hal tersebut didukung oleh hasil penelitian terdahulu pada tahun 2019 yaitu IMT normal sebanyak 96 responden (59\%) lebih besar dibandingkan obesitas, status gizi gemuk, dan kurus. Sejalan dengan hasil penelitian Driyah dkk. (2019), menunjukkan hanya 789 responden dari 4.215 responden mengalami status gizi gemuk $(18,7 \%)$.

Hasil analisis didapat $p$ value 0,262 sehingga tidak ada hubungan antara IMT dengan sindrom metabolik. Penelitian Rachmah \& Utari (2013), uji korelasi IMT dengan sindrom metabolik pada guru sekolah dasar di kecamatan Cilandak didapat nilai $p$ value $<0,05$ sehingga terdapat hubungan yang signifikan antara IMT dengan sindrom metabolik. Hal tersebut sejalan dengan penelitian Driyah dkk. (2019, hlm.218), dilihat dari indikator IMT terdapat hubungan yang bermakna dengan sindrom metabolik. Responden yang berisiko sindrom metabolik yaitu dengan status gizi obesitas.

Kondisi tingginya akumulasi pada jaringan lemak terutama pada lemak viseral ditandai dengan pembesaran sel-sel lemak sehingga memproduksi produk metabolik (Jafar, 2012, hlm.72). Obesitas berkontribusi dalam tingginya kolesterol, dan rendahnya LDL serta produk angiotensinogen dapat meningkatkan tekanan darah yang drastis (IDF, 2006, p.7; Xu et al., 2019, p.8). Produk tersebut memicu terjadinya penyakit metabolik seperti hipertensi, dan dislipidemia.

Sejalan dengan penelitian di salah satu pesentren daerah Ngawi yaitu tidak ada hubungan signifikan antara IMT dengan sindrom metabolik (Choirotussanijah, 2019, hlm.26). Penelitian Entika 
dkk. (2017, hlm.8), menunjukkan $p$ value sebesar 0,312 bahwa tidak ada hubungan antara antara IMT dengan sindrom metabolik pada pasien rawat jalan di RSUD Dr. Moewardi.

Selain itu, nilai OR pada uji statistik menunjukkan 3,444 kali bahwa seseorang tidak obesitas memiliki peluang tidak menderita sindrom metabolik. Penelitian Effendi dkk. (2013) dalam Refdanita

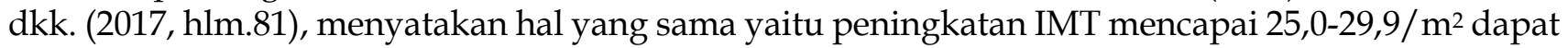
menyebabkan masalah kesehatan secara bersamaan. Hal didukung dengan hasil penelitian Kamso dkk. (2011, hlm.88), bahwa pada pegawai eksekutif dengan analisis regresi menyatakan hasil bahwa status gizi overweight memiliki risiko 5,54 kali lipat sindrom metabolik, sedangkan status gizi obesitas memiliki risiko 7,44 kali sindrom metabolik dibandingkan dengan status gizi normal. Hasil yang serupa menunjukkan responden yang berstatus gizi obesitas memiliki risiko 6,3 kali lebih besar termasuk sindrom metabolik dibandingkan responden berstatus gizi tidak obesitas (Wiardani \& Arsana, 2011 dalam Refdanita dkk., 2017, hlm.81). Kelebihan penelitian ini yaitu belum dilakukan uji hubungan di perusahaan tersebut mengenai asupan makan dan satus gizi dengan sindrom metabolik. Penelitian ini memiliki kelemahan yaitu dilakukan food recall 24 jam melalui google form, wawancara melalui chat, dan tidak melakukan pengukuran antropometri secara langsung dikarenakan keterbatasan peneliti selama pandemik Covid-19.

\section{SIMPULAN}

Kejadian sindom metabolik yaitu sebanyak empat kasus (6,5\%). Tidak terdapat hubungan antara asupan zat gizi makro dan IMT dengan sindrom metabolik ( $p$ value $>0,05)$. Nilai OR pada uji statistik IMT menunjukkan 3,444 kali bahwa seseorang tidak obesitas memiliki peluang tidak menderita sindrom metabolik. Saran bagi penelitian selanjutnya diharapkan dengan melakukan wawancara mendalam terkait food recall 24 jam, pengukuran tinggi badan, penimbangan berat badan secara langsung, serta menggunakan data medical check-up pada bulan yang sama dengan penelitian.

\section{SARAN}

Saran bagi penelitian selanjutnya diharapkan dengan melakukan wawancara mendalam terkait food recall 24 jam, pengukuran tinggi badan, penimbangan berat badan secara langsung, serta menggunakan data medical check-up pada bulan yang sama dengan penelitian.

\section{DAFTAR PUSTAKA}

Almatsier, S. (2009). Prinsip Dasar Ilmu Gizi. Gramedia Pustaka Utama. Jakarta

Afifah, Hana Mutia, Hartriyanti, Yayuk, dan Samekto, Perdana. (2018). Hubungan Antara Asupan Zat Gizi dan Status Gizi Dengan Sindrom Metabolik Pada Wanita Pengrajin Batik. http://etd.repository.ugm.ac.id/home/detail_pencarian/132007

[diakses pada tanggal 19 Januari 2019]

Chegarya, M. et al. (2009). Mitochondrial Long Chain Fatty Acid $\beta$-oxidation in Man and Mouse. NIH Public Access, 1791(8): 806-815. doi: 10.1016/j.bbalip.2009.05.006.Mitochondrial.

Choirotussanijah, K. (2019). Hubungan Status Gizi ( Indikator IMT ) Terhadap Kejadian Metabolic Syndrome di Pondok Pesantren Al-Hidayah , Kabupaten Ngawi 2018. Medical Technology and Public Health Journal, 3(1): 23-28.

Damayanti, Didit, Pritasari, dan Nugraheni Tri L. (2017). Buku Ajar Gizi: Gizi Dalam Daur Kehidupan. Kementerian Kesehatan RI: Pusat Pendidikan Sumber Daya Manusia Kesehatan.

Davy, B. M. et al. (2014). Impact of Individual and Worksite Environmental Factors on Water and Sugar-Sweetened Beverage Consumption Among Overweight Employees. Preventing Chronic Disease, 11(1): 1-9.

Driyah, S. et al. (2019). Prediktor Sindrom Metabolik: Studi Kohor Prospektif Selama. Media Litbangkes, 29(3): 215-224.

Entika, Rieny Hutami. (2017). Hubungan Status Gizi dan Sindrom Metabolik dengan Kejadian Komplikasi Pasiesn Diabetes Mellitus Tipe 2 Rawat Jalan di RSUD Dr. Moewardi. Universitas Muhammadiyah Surakarta

Fahad, Muhammad. (2013). Hubungan Pola Makan dengan Metabolic Syndrome dan Gambaran Aktivitas 
Fisik Anggota Klub Senam Jantung Sehat Kampus II Universitas Islam Negeri (UIN) Syarif Hidayatullah Tahun 2013. Universitas Islam Negeri (UIN) Syarif Hidayatullah Jakarta.

IDF. (2006). Metabolic Syndrome. International Diabetes Federation, p. 7.

Jafar, N. 2012. Sindroma metabolik dan epidemiologi metabolic syndrome and epidemiology. Media Gizi Masyarakat Indonesia, 1(2): 71-78.

Kamso, S. et al. (2011). Prevalensi dan Determinan Sindrom Metabolik pada Kelompok Eksekutif di Jakarta dan Sekitarnya. Jurnal Kesehatan Masyarakat Nasional, 6(2): 85-90.

Lim, Hyo Kyung et al. (2018). Relationship of Metabolic Diseases with Physical Activity Depending on Age. Korean Jounal Clinical Laboratory Science, 50 (2): 144-154

Mitchell, R. J. and Bates, P. (2011). Measuring Health-Related Productivity Loss. Population Health Management, 14(2): 93-98. doi: 10.1089/pop.2010.0014.

Mukhlis, Suhardi. (2012). Administrasi Kepegawaian. Letikaprio. Yogyakarta.

Notoatmodjo, Soekidjo. (2012). Metodologi Penelitian Kesehatan. Rineka Cipta. Jakarta

Perwiranti, E. C. et al. (2017). Perbedaan asupan energi, zat gizi, dan indeks massa tubuh antara sebelum dengan selama puasa ramadan pada anggota militer. Jurnal Ilmu Faal Olahraga, 1(2): 24-32.

Putri, L. P. and Dieny, F. F. (2016). Hubungan Densitas Energi dan Asupan Zat Gizi Makro dengan Kejadian Sindrom Metabolik Pada Remaja Obesitas. Journal of Nutrition Collage, 5(3): 214-221.

Rachmah, Q. and Utari, D. M. (2013). Indeks Massa Tubuh ( IMT ) sebagai Faktor Predominan terhadap Sindrom Metabolik pada Guru Sekolah Dasar di Kecamatan Cilandak. Jakarta Selatan ', FKM UI.

Ranti, I., Rumagit, F. and Montol, A. (2013). Aktivitas Fisik dan Total Asupan Lemak Terhadap Komponen Sindrom Metabolik Pada Pegawai dan Staf Politeknik Kesehatan Manado. GIZIDO, 5(2): 127-139.

Refdanita et al. (2017). Hubungan Karakteristik Pria Dewasa dengan Biomarker Sindroma Metabolik. Jurnal Gizi Pangan, 12(2): 79-84. doi: 10.25182/jgp.2017.12.2.79-84.

Rini, S. (2015). Sindrom Metabolik. J Majority, 4(4): 88-93.

Rini, T. P. et al. 2014. Gambaran Kadar Kolesterol Pasien yang Mendapatkan Terapi Bekam. JOM PSIK, 1(2): 1-8.

Rismayanthi, C. et al. (2019). Penyuluhan Aktivitas Fisik dan Screening Parameter Sindrom Metabolik Pada Populasi Lansia. MEDIKORA, XVIII(1): 33-39.

Sargowo, D. and Andarini, S. (2011). The Relationship Between Food Intake and Adolescent Metabolic Syndrome. Jurnal Kardiologi Indonesia, 32(1): 14-23.

Widyastuti, N., Sulchan, M. and Johan, A. (2013). Asupan Makan, Sindrom Metabolik, dan Status Keseimbangan Asam-basa pada Lansia. Jurnal Gizi Klinik Indonesia, 9(4): 179-187.

$\mathrm{Xu}, \mathrm{H}$. et al. (2019). Etiology of Metabolic Syndrome and Dietary Intervention. International Journal of Molecular Sciences, 20(128): 1-19. doi: 10.3390/ijms20010128.

Yuliantini, E., Sari, A. P. and Nur, E. (2015). Hubungan Asupan Energi, Lemak dan Serat dengan Rasio Kadar Kolesterol Total-HDL. Penelitian Gizi dan Makanan, 38(2): 139-147.

Zahtamal et al. (2014). Prevalensi Sindrom Metabolik pada Pekerja Perusahaan. Jurnal Kesehatan Masyarakat Nasional, 9(2): 113-120. 